\title{
Productivity regime and phytoplankton size structure in the Arabian Sea
}

\author{
Frank J. Jochem, ${ }^{*}$ Falk Pollehne* and Bernt Zeitzschel. \\ (First received 19 March 1991; in revised form 8 July 1992; accepted 24 November 1992)
}

\begin{abstract}
The productivity regime and size structure of phytoplankton are described for three different epipelagic systems in the Arabian Sea during the inter-monsoon period in spring 1987: (1) the coast of Oman; (2) the central Arabian Sea; and (3) the shelf off Pakistan. These results are related to the functioning of the specific ecosystem. Off the coast of Oman, the transition from a surface maximum of autotrophic biomass and production to a more oligotrophic system, with a chlorophyll subsurface maximum, was observed. Concomitantly, the size spectrum changed towards a higher significance of picoplankton. In the central Arabian Sea, a typical oligotrophic system with a pronounced subsurface maximum of autotrophic biomass and primary production was encountered. Here, the epipelagic system could be divided into two distinct sub-systems: the surface layer "regenerated" production, the predominance of picophytoplankton and minor losses due to sedimentation, thus a "closed" system; and the subsurface maximum layer at the nutricline characterized by higher sedimentation losses and more diatoms. Both sub-systems showed about the same productivity, the turnover in the surface layer having been much greater than in the subsurface maximum. The system on the shelf off Pakistan is seen as a decay stage of the open ocean system when water from offshore is transported onto the shelf during the onset of monsoon winds.
\end{abstract}

\section{INTRODUCTION}

THE Indian Ocean is distinguished from the Atlantic and Pacific oceans by the Arabian continent which closes it to the north at $25^{\circ} \mathrm{N}$ and causes a variety of specific climatic and hydrographic features. The northeastern part of the Indian Ocean, the Arabian Sea, is one of the most productive oceanic provinces (RYTHER et al., 1966), because of the special hydrographic situation in this area (SASTRY and DeSouZA, 1972; QASIM, 1982).

A great effort to investigate the Indian Ocean was undertaken by the International Indian Ocean Expedition 1959-1965 (ZeITzsches, 1973). Since then, however, relatively little information on this ocean has been published in comparison to the Atlantic and Pacific Ocean. Another expedition has been described by ANGEL (1983).

Data presented here were obtained during cruise no. 5 of the German Research Vessel Meteor from March to June 1987. Since the investigation period fell within the intermonsoon period, no, or only minor, upwelling could be expected south of the Arabian peninsula, and since it was the warmest and driest period of the year the outflow of the Indus River could be expected to be negligible. High temperatures should lead to a

\footnotetext{
*Institut für Meereskunde an der Universität Kiel, Düsternbrooker Weg 20, 2300 Kiel, Germany.
} 


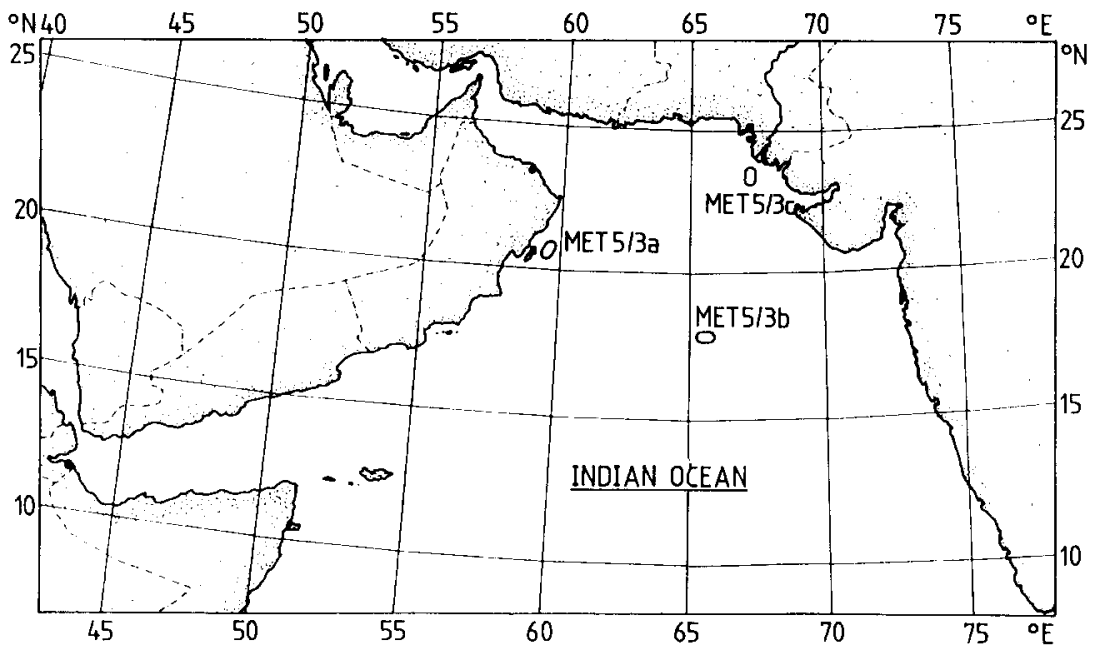

Fig. 1. Study sites of R.V. Meteor cruise no. 5 into the Arabian Sea in spring 1987: MET5/3a off the coast of Oman; MET5/3b in the central Arabian Sea; and MET5/3c on the shelf off Pakistan.

thermally stratified and stable water column and more or less oligotrophic conditions in the surface layer.

We describe here three different epipelagic systems: (1) the coast of Oman, (2) the central Arabian Sea; and (3) the shelf off Pakistan (Fig. 1). The productivity regime and the size structure of phytoplankton have been studied and set in relation to the general characteristics and functioning of the specific ecosystem. It will be shown that the significance of the autotrophic picoplankton is generally comparable to that in the Atlantic and Pacific Oceans, and that a close relationship between the ecosystem's functioning and the size distribution of plankton can be established.

\section{MATERIALS AND METHODS}

Leg $3 \mathrm{a}$ of R.V. Meteor cruise no. 5 was situated off the coast of Oman at $21^{\circ} \mathrm{N}, 60^{\circ} \mathrm{E}$, mean depth about $2000 \mathrm{~m}$. The 14 days drogue station lasted from 29 March to 11 April. Leg $3 \mathrm{~b}$, in the central Arabian Sea, took place at $18^{\circ} \mathrm{N}, 65^{\circ} \mathrm{E}$, mean depth $3300 \mathrm{~m}, 29$ April-12 May. The last leg, $3 \mathrm{c}$, was situated on the shelf off Pakistan at $23^{\circ} \mathrm{N}, 67^{\circ} \mathrm{E}$, mean depth $115 \mathrm{~m}$, drift period 22 May-2 June.

Since the vertical structure of dynamic processes of the epipelagic system was the main goal of this study, a "Lagrangian" drogue study was carried out. Samples were taken along the track of a drifter carrying sediment traps just below the euphotic zone $(80-120 \mathrm{~m})$. During sampling, the ship stayed as close as possible to the drifter. A detailed description of the drifter itself is given elsewhere (PASsow et al., 1993; Pollenne et al., 1993b).

Temperature and salinity profiles were taken with a Kiel Multisonde (ME Electronic, Trappenkamp, Germany). In situ chlorophyll fluorescence was recorded by a Variosens fluorescence probe and analog data output.

Water samples were taken with a 12 bottle multisampler with black 12 I Niskin type water bottles. Dissolved inorganic nutrients $\left(\mathrm{NO}_{3}, \mathrm{NO}_{2}, \mathrm{PO}_{4}\right.$, silicate) were measured 
according to Grasshoff et al. (1983) with an autoanalyzer. Samples were filtered onto 25 $\mathrm{mm}$ Whatman GF/F filters, except for particulate silicate analysis where $0.45 \mu \mathrm{m}$ membrane filters were used. Particulate organic carbon and nitrogen were estimated using a Perkin-Elmer B-140 elemental analyzer, after the removal of inorganic carbonates with hydrochloric acid. Particulate silicate was measured according to PAAsche (1980). These values were slightly underestimated due to analytical problems, but linearity of the measurements was verified. Chlorophyll $a$ was determined either trichromatically (STRICKLAND and PARSONS, 1972) and calculated after JEFFrEY and HUMPHREY (1975), or with a Turner Designs Model 10 fluorometer calibrated against trichromatically determined Chl $a$.

Primary production was measured by in situ $\mathrm{H}^{14} \mathrm{CO}_{3}$ incubations (STEEMANN NIELSEN, 1952) of 5-6 h duration (sunrise-local noon) in $250 \mathrm{ml}$ glass bottles $(25 \mu \mathrm{Ci} / \mathrm{bottle})$. [During leg $3 \mathrm{a}$, an additional afternoon incubation (local noon-sunset) was performed]. Threefour bottles, treated with $10^{-5} \mathrm{~mol} \mathrm{l}^{-1}$ DCMU [3-(3,4-dichlorphenyl)-1,1-dimethylurea; LEGENDRE et al., 1983], were used as a dark correction and subtracted from light bottles. After incubation, samples were treated with $1.5 \times 10^{-5} \mathrm{~mol} \mathrm{l}^{-1} \mathrm{DCMU}$ to prevent carbon uptake. ${ }^{14} \mathrm{C}$-uptake was determined by liquid scintillation measurements in a Packard TriCarb.

For size fractionation into the size classes "total", " $<20 \mu \mathrm{m}$ " and " $<2 \mu \mathrm{m}$ ", postincubation screening was used. For each depth, one light bottle was incubated. Seventyfive $\mathrm{ml}$ aliquots were used for fractionation, to avoid variance because of different bottles. Estimates for "total" were obtained from untreated aliquots, the other two aliquots were filtered through $20 \mu \mathrm{m}$ net gauze and $25 \mathrm{~mm} 2.0 \mu \mathrm{m}$ Nuclepore filters (pressure $<300$ $\mathrm{mbar}$ ), respectively. The filtrates were again filtered onto $0.45 \mu \mathrm{m}$ membrane filters. The same size fractionation procedure was used for chlorophyll, but 21 were fractionated and the filtrates were filtered onto Whatman GF/F. For $<2 \mu \mathrm{m}$ fractionation of chlorophyll, three filters were used for each 21 sample.

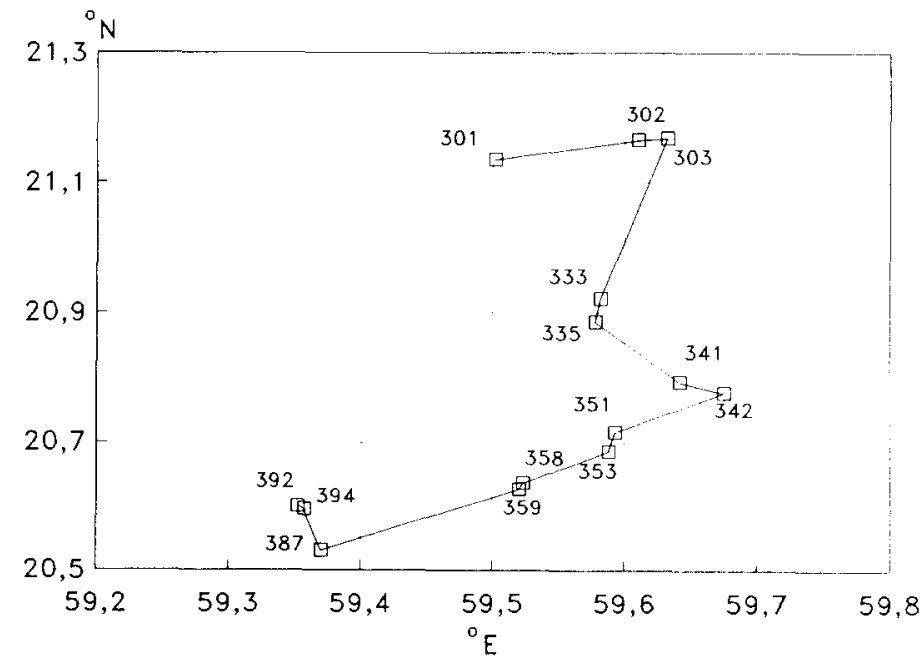

Fig. 2. Drifter trajectory of the drogue station off the coast of Oman, leg 3a. Station numbers indicated. 
(a) $28, \quad 250 \quad 262 \quad 2 \pi 4 \sigma_{0}$

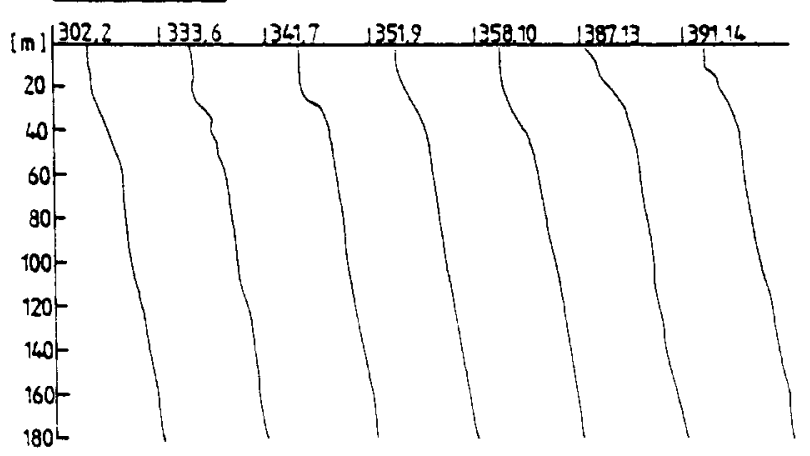

(b) $360 \quad 364 \quad 368 \quad 372 \%$

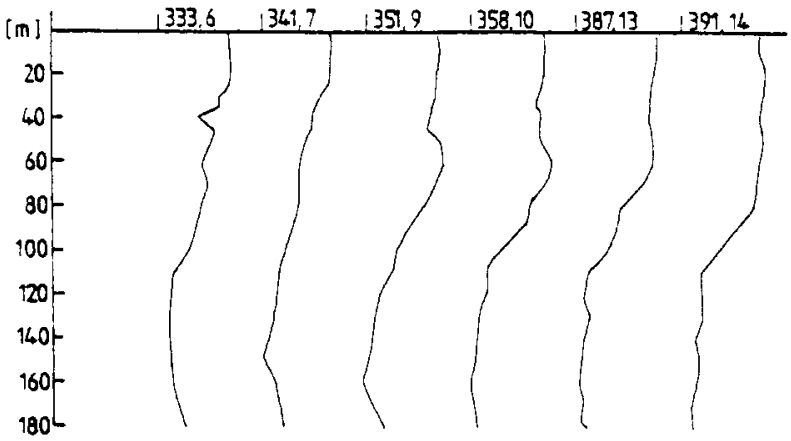

(c) $9529,24,27 \times$

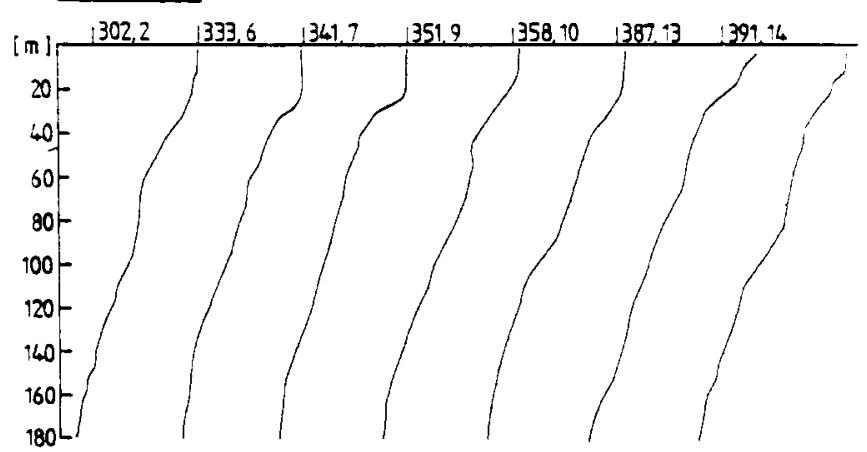

Fig. 3. Profiles of density $\sigma_{\theta}(\mathrm{a})$, temperature $\left({ }^{\circ} \mathrm{C} ; \mathrm{b}\right)$, and salinity $(\% ; \mathrm{c})$ on leg $3 \mathrm{a}$. Number: indicate station and day of drift study. 
(a)

$\sin 303$ Nut

$\left[\mu \mathrm{moll}^{-1}\right]$

$[m] 0 \quad 5 \quad 10 \quad 15 \quad 20$

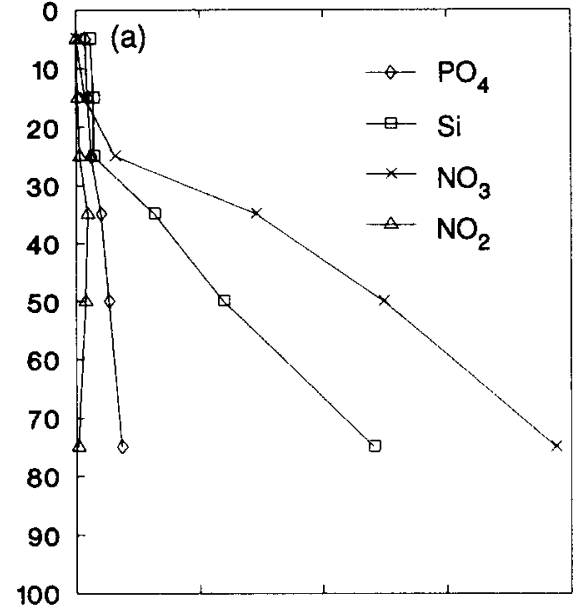

(b)

$\sin 391$ Nut

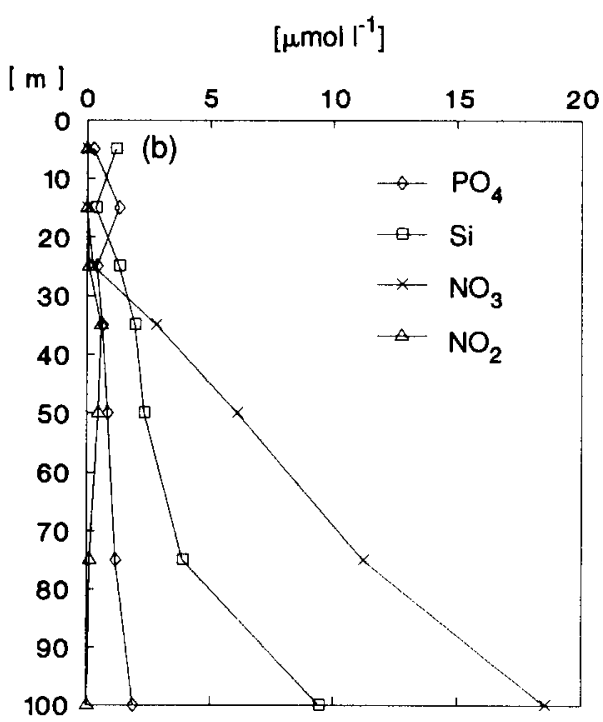

Fig. 4. Inorganic nutrients $\left(\mu \mathrm{mol} 1^{-1}\right)$ on leg 3a; (a) Sta. 303, day 2; (b) Sta. 391, day 14. 


\section{RESULTS}

\section{Leg 3a: the coast of Oman}

The drogue station off the coast of Oman was investigated over three periods: the first 2 days (Stas 301-303); days 6-10 (Stas 333-359); and days 13 and 14 (Stas 387-392) (Fig. 2).

Surface temperature [Fig. 3(c)] was $25.0-26.5^{\circ} \mathrm{C}$ and increased slightly over the investigation period; surface salinity ranged from 36.5-36.7\% [Fig. 3(b)]. A thermocline, prominent at about $20 \mathrm{~m}$ depth but at $10 \mathrm{~m}$ on the last day [Fig. 3(c)], defined the density structure $\left[\sigma_{\theta} ;\right.$ Fig. 3(a)] and the depth of the surface layer. During drift phase II (Stas 351, 358 ), a region of higher salinity was found at 50-80 m depth, which might have been the "Arabian Sea High Salinity Water" (Gallagher 1966). On the last 2 days, however, salinity was almost constant down to the halocline at 65 and $85 \mathrm{~m}$ depth, respectively. Changes in the hydrographic structure suggest that the drifter did not stay within the same water body but moved into another one between days 7 and 9 (Stas 341 and 351). A change in the drift trajectory, from cyclonic to straight westward (Fig. 2) confirms the change in hydrographic conditions. Data presented here, therefore, cannot be seen as a true time series. Data elaborated on two $40 \times 80$ miles grids comprising 40 stations around the drogue (PAssow et al., 1993) indicated that the "temporal" development of the epipelagic system observed near the drifter was, however, representative for the temporal development of the whole area.

Nutrient concentrations [Fig. 4(a) and (b)] in the surface layer were $0.4-0.5 \mu \mathrm{mol} \mathrm{l}^{-1}$ of phosphate, about $1.2 \mu \mathrm{mol} \mathrm{I}{ }^{-1}$ of silicate, less than $0.03 \mu \mathrm{mol} \mathrm{l}^{-1}$ of nitrite. The latter exhibited a primary maximum (up to $0.9 \mu \mathrm{mol}^{-1}$ ) at $35-50 \mathrm{~m}$ depth. Nitrate was measurable at $<0.3 \mu \mathrm{mol}^{-1}$ in the surface layer at the beginning of the study; at the end, it was detectable only below $30 \mathrm{~m}$, and concentrations in the lower part of the euphotic zone (30-75 m) decreased with time.

Vertical profiles of in situ fluorescence (Fig. 5) were very "spiky" during the first half of the study period, suggesting the occurrence of larger phytoplankton. Between days 7 and 9 (Stas 341 and 351), the fluorescence profiles became much smoother and the subsurface

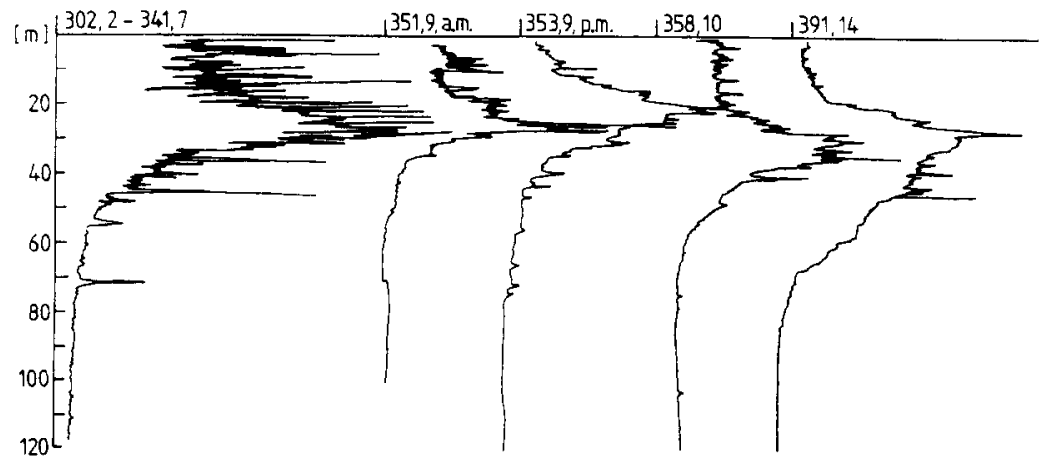

Fig. 5. In situ fluorescence on leg 3a, arbitrary units. Numbers indicate station and day of drift study. 
(a)

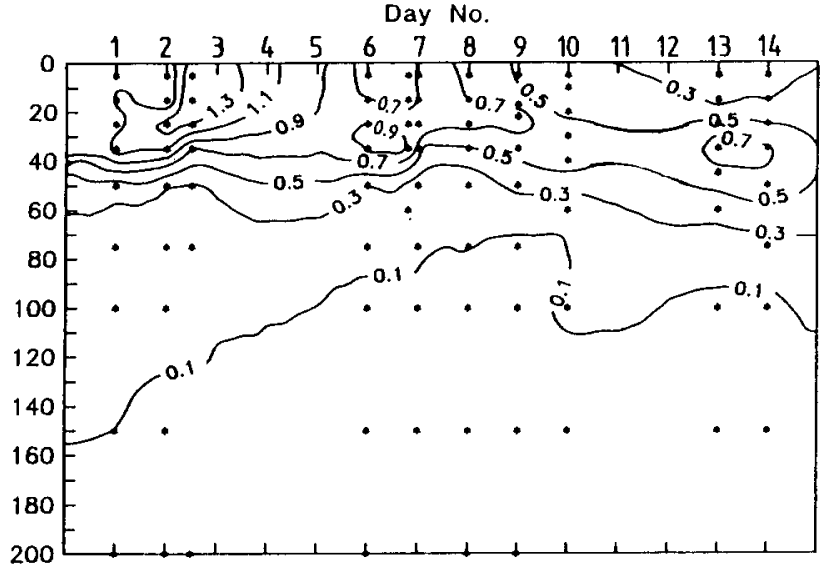

(b)

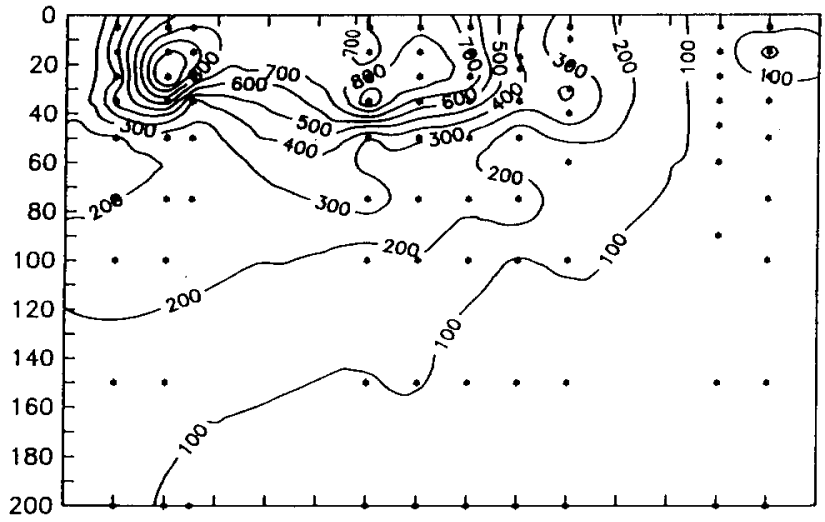

(c)

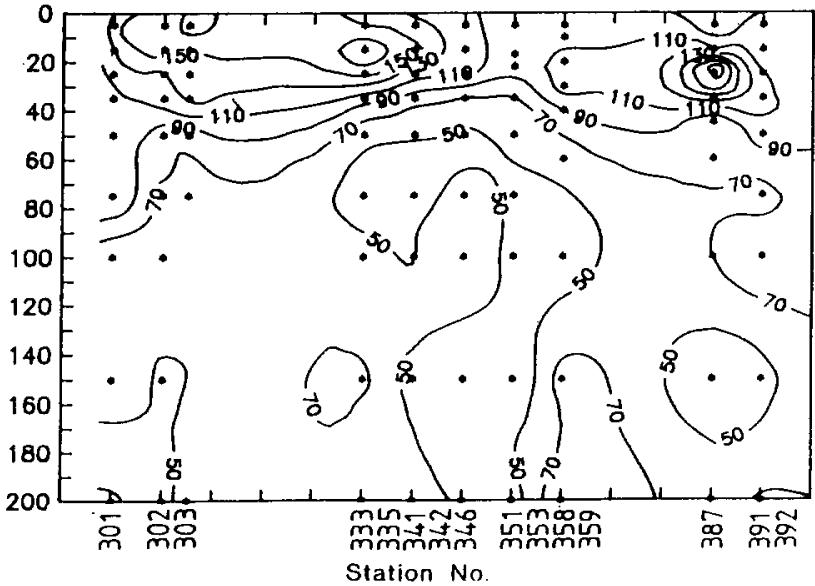

Fig. 6. Profiles of (a) chlorophyll $a$ (b) particulate silicate; and (c) particulate organic carbon on leg $3 \mathrm{a}$, all in $\mu \mathrm{g} \mathrm{I}^{-1}$. 


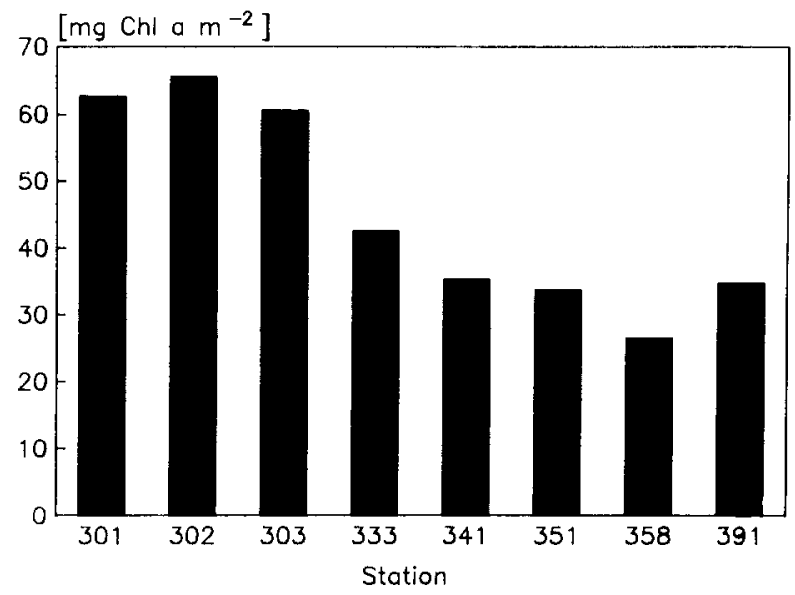

Fig. 7. Integrated chlorophyll $a(0-75 \mathrm{~m})$ on $\operatorname{leg} 3 \mathrm{a}\left(\mathrm{mg} \mathrm{m}^{-2}\right)$.

maxima [Fig. 6(a)] became more pronounced, whilst the surface layer fluorescence decreased. Integrated chlorophyll decreased from $60 \mathrm{mg} \mathrm{m}^{-2}$ to $30-35 \mathrm{mg} \mathrm{m}^{-2}$ (Fig. 7).

The decrease and change in the vertical distribution of chlorophyll was concomitant with a significant decrease in particulate silicate, an indicator of diatoms, especially after day 9 [Fig. 6(b)]. At the end of the investigation period only $1 / 8$ of the concentration of chlorophyll was present compared with the beginning.

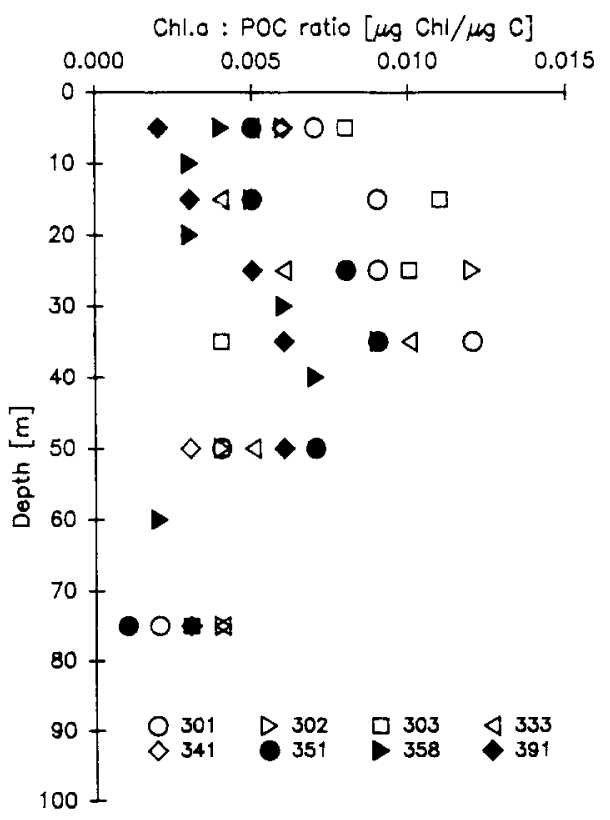

Fig. 8. Chl a/POC ratios on leg 3a. 


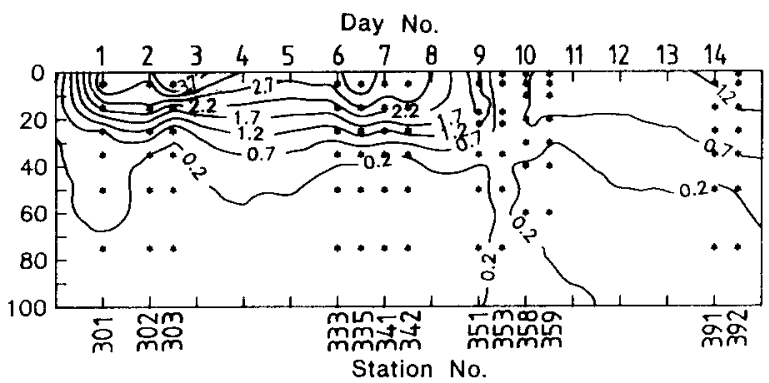

Fig. 9. Primary production $\left(\mu \mathrm{g} \mathrm{C} 1^{-1} \mathrm{~h}^{-1}\right)$ on leg $3 \mathrm{a}$.

The decrease in autotrophic biomass was not reflected by similar decreases in particulate organic carbon [POC; Fig. 6(c)] and particulate organic nitrogen (not depicted here). However, the maximum of POC was found in subsurface layers towards the end of the study, but the concentration was in the same range as at the start (up to more than $150 \mu \mathrm{g} \mathrm{C}$ $\mathrm{1}^{-1}$ ). Throughout the upper $200 \mathrm{~m}$ of water column, atomic $\mathrm{C} / \mathrm{N}$ ratios of particulate matter were 5.5-6.5, with no obvious trend with depth, but exhibited a tendency towards lower ratios at the end of the study period. Low $\mathrm{C} / \mathrm{N}$ ratios, being close to those of bacteria and small phytoplankton, suggest a minor contribution of detrital material to POC. Chl $a / \mathrm{POC}$ ratios (Fig. 8) were high in the surface waters during the first half of the study period, with maximum values at $20-40 \mathrm{~m}$ depth and a sharp decrease below $40 \mathrm{~m}$. Towards the end of the study, the ratios in surface waters were lower and constant down to the depth of the subsurface maximum, and the sharp decrease did not occur until below $50 \mathrm{~m}$ depth.

Primary production always showed a surface maximum, which was most pronounced during the first and second drift phase (Fig. 9). At the surface, more than $3 \mu \mathrm{g} \mathrm{C}^{-1} \mathrm{~h}^{-1}$ were generally measured and productivity sharply decreased below $30 \mathrm{~m}$ depth. The productivity regime also changed after day 9 (Sta. 341), when primary production decreased, and the surface maximum was less obvious. Integrated production (Fig. 10)

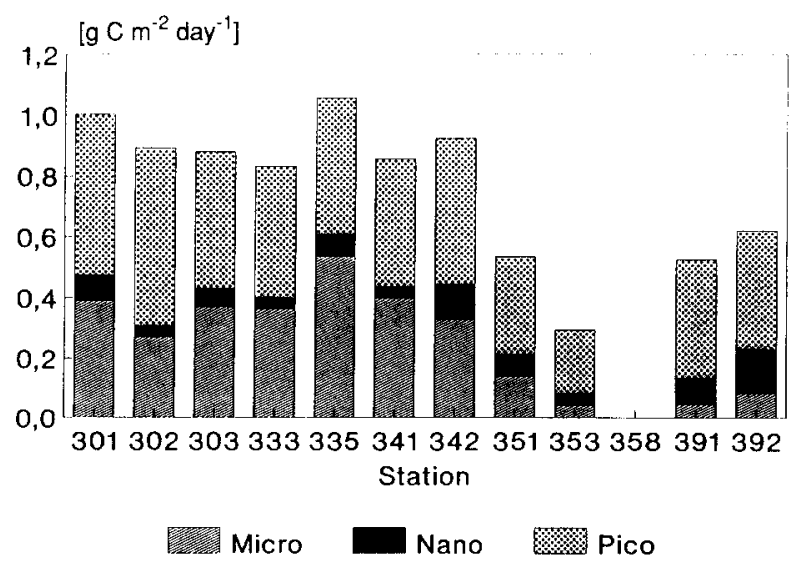

Fig. 10. Daily integrated, size-fractionated primary production $\left(0-75 \mathrm{~m} ; \mathrm{g} \mathrm{C} \mathrm{m}^{-2} \mathrm{day}^{-1}\right)$ on leg 3a. Pico- $<2 \mu \mathrm{m}$; nano- $2-20 \mu \mathrm{m}$; micro- $>20 \mu \mathrm{m}$. 


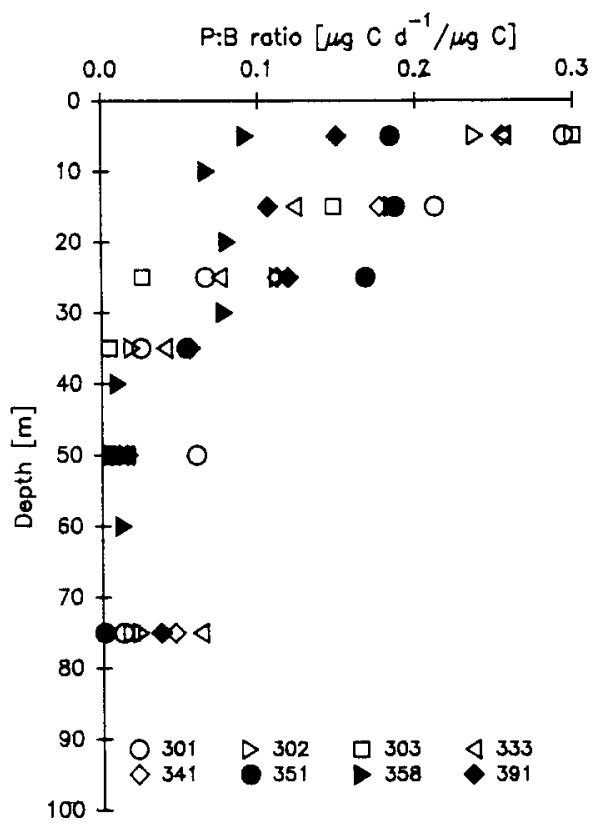

Fig. 11. P:B ratios (daily primary production to particulate organic carbon) on leg $3 \mathrm{a}$.

Table 1. Size fractionation of euphotic zone chlorophyll and primary productivity. Chlorophyll given in $\mathrm{mg} \mathrm{m}^{-2}$, production in $\mathrm{g} \mathrm{C} \mathrm{m}^{-2} \mathrm{day}^{-1}$

\begin{tabular}{|c|c|c|c|c|c|c|c|}
\hline Station & Total & Micro- & Nano- & Pico- & $\%$ Micro- & $\%$ Nano- & $\%$ Pico- \\
\hline \multicolumn{8}{|l|}{ Leg $3 a$} \\
\hline \multicolumn{8}{|c|}{ Chlorophyll } \\
\hline 301 & 62.7 & 22.1 & 10.7 & 29.9 & 35.2 & 17.2 & 47.6 \\
\hline 302 & 65.6 & 34.2 & 1.9 & 29.5 & 52.1 & 2.9 & 45.0 \\
\hline \multicolumn{8}{|l|}{ Leg $3 b$} \\
\hline \multicolumn{8}{|c|}{ Chlorophyll } \\
\hline 432 & 31.0 & 4.5 & 2.5 & 24.0 & 14.5 & 8.0 & 77.5 \\
\hline 465 & 35.8 & 7.7 & 4.4 & 23.7 & 21.5 & 12.1 & 66.4 \\
\hline 493 & 28.7 & 6.3 & 1.6 & 20.8 & 21.8 & 5.4 & 72.8 \\
\hline \multicolumn{8}{|c|}{ Production } \\
\hline 432 & 0.70 & 0.09 & 0.20 & 0.40 & 13.6 & 28.3 & 58.1 \\
\hline 463 & 0.74 & 0.06 & 0.14 & 0.54 & 8.0 & 19.2 & 72.8 \\
\hline 464 & 0.68 & 0.06 & 0.11 & 0.51 & 8.7 & 15.7 & 75.6 \\
\hline 465 & 0.79 & 0.06 & 0.14 & 0.59 & 7.8 & 17.5 & 74.7 \\
\hline \multicolumn{8}{|l|}{$\operatorname{Leg} 3 c$} \\
\hline \multicolumn{8}{|c|}{$\overline{\text { Chlorophyll }}$} \\
\hline 560 & 26.4 & 1.8 & 0.2 & 24.4 & 6.9 & 0.6 & 92.5 \\
\hline \multicolumn{8}{|c|}{ Production } \\
\hline 552 & 0.18 & 0.02 & 0.02 & 0.14 & 10.4 & 9.9 & 79.7 \\
\hline 555 & 0.31 & 0.06 & 0.05 & 0.20 & 18.0 & 15.3 & 66.7 \\
\hline 560 & 0.35 & 0.01 & 0.02 & 0.32 & 4.2 & 5.7 & 90.1 \\
\hline
\end{tabular}


decreased from about $1 \mathrm{~g} \mathrm{C} \mathrm{m}^{-2} \mathrm{day}^{-1}$ to less than $0.6 \mathrm{~g} \mathrm{C} \mathrm{m}^{-2}$ day $^{-1}$. Whereas chlorophyll concentrations decreased after Sta. 333 (day 6) productivity did not decrease until Sta. 351 (day 9). Differences of daily integrated production based on morning and afternoon incubations were only minor, tending to slightly higher values in afternoon incubations due to higher values in the micro- and nanoplankton size fractions.

$\mathrm{P}$ : B ratios (Daily primary production/POC; Fig. 11) showed a steady decrease with depth during the first half of the study period; the shape of the curve strongly resembles that of light penetration into the ocean. After the changes related to Sta. 341, P: B ratios in the surface waters were lower and constant down to $30 \mathrm{~m}$, and sharply decreased below.

All size fractions exhibited surface maxima of primary production. During the first half of the study, productivity was dominated by micro- $(>20 \mu \mathrm{m})$ and picoplankton $(<2 \mu \mathrm{m})$ (Fig. 10), producing $0.3-0.5 \mathrm{~g} \mathrm{C} \mathrm{m}^{-2} \mathrm{day}^{-1}\left(30-51 \%\right.$ of the total) and $0.45-0.6 \mathrm{~g} \mathrm{C} \mathrm{m}^{-2}$ day $^{-1}(52-66 \%$ of the total $)$, respectively. The nanoplankton $(2-20 \mu \mathrm{m})$ contribution was minor $\left(0.03-0.08 \mathrm{~g} \mathrm{C} \mathrm{m}^{-2} \mathrm{day}^{-1}, 4-8 \%\right)$. The same size distribution was reflected in chlorophyll measurements (Table 1). After day 9 (Sta. 351), all size fractions showed reduced productivity but this was most pronounced for microplankton, accounting for only $0.04-0.14 \mathrm{~g} \mathrm{C} \mathrm{m}^{-2} \mathrm{day}^{-1}(9-26 \%$ of the total). Nanoplankton production slightly increased to $0.04-0.14 \mathrm{~g} \mathrm{C} \mathrm{m}^{-2} \mathrm{day}^{-1}(12-23 \%$ of the total). Picoplankton (about $0.4 \mathrm{~g} \mathrm{C}$ $\mathrm{m}^{-2} \mathrm{day}^{-1}, 60-74 \%$ ) became the dominant size fraction.

\section{Leg $3 b$ : the central Arabian Sea}

The drogue station in the central Arabian Sea also was investigated during three drift phases: the first two days (Stas 432-434); days 6-9 (Stas 463-466); days 13 and 14 (Stas 493-495). Throughout the whole investigation period, the drogue showed a straight southeasterly drift trajectory (Pollehne et al., 1993a).

The hydrographic regime displayed only very minor changes over the whole investigation period, as well as within a $40 \times 80$ miles grid, comprising 40 stations around the drifter which was surveyed twice (PollenNe, unpublished data). Typical profiles of temperature, salinity and density $\left[\sigma_{\theta}\right.$; Sta. 465 (day 8); Fig. 12] showed a strong pycnocline

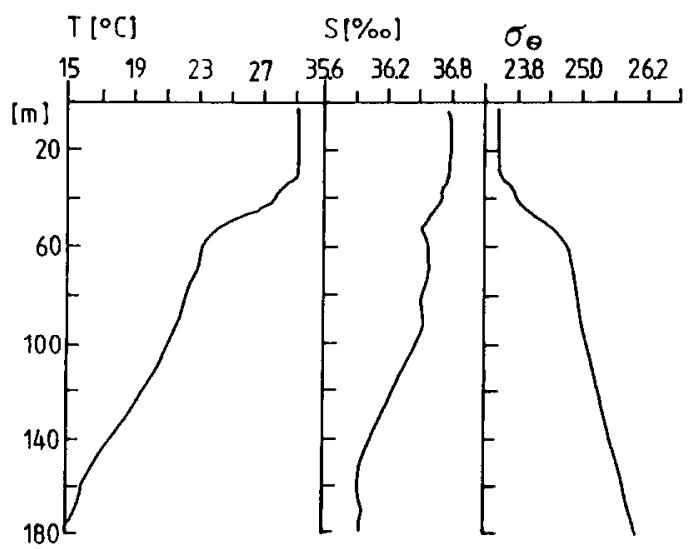

Fig. 12. Profiles of temperature $\left({ }^{\circ} \mathrm{C}\right.$ ), salinity (\%) and density $\sigma_{\theta}$ at Sta. 465 (day 8 ) on leg 3 b. 


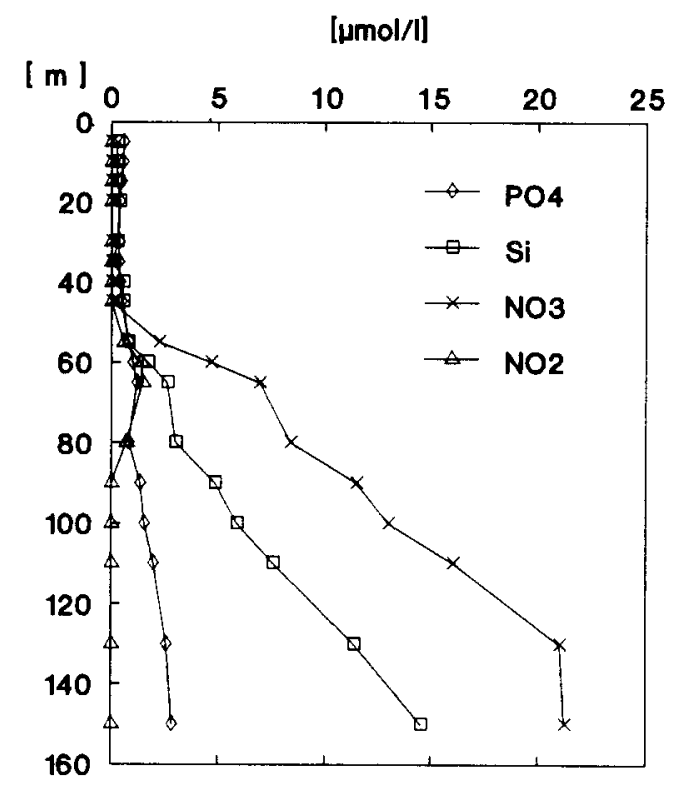

Fig. 13. Inorganic nutrients $\left(\mu \mathrm{mol}^{-1}\right)$ at Sta. 466 (day 9) on leg 3b.

at $20-30 \mathrm{~m}$ depth. Surface temperature ranged from 28.0 to $29.5^{\circ} \mathrm{C}$, being significantly higher than on leg $3 a$, and surface salinity was $36.5-36.8 \%$.

Almost no changes in nutrient concentrations could be observed over the investigation period. Surface layer concentrations were $0.3-0.4 \mu \mathrm{mol}^{-1}$ of phosphate and $0.4-1.0 \mu \mathrm{mol}$ $\mathrm{I}^{-1}$ of silicate. Nitrite showed a maximum of up to $1.4 \mu \mathrm{mol} \mathrm{l}^{-1}$ at $50-80 \mathrm{~m}$ depth, being undetectable above and below this depth. Nitrate was mostly below the limit of detection

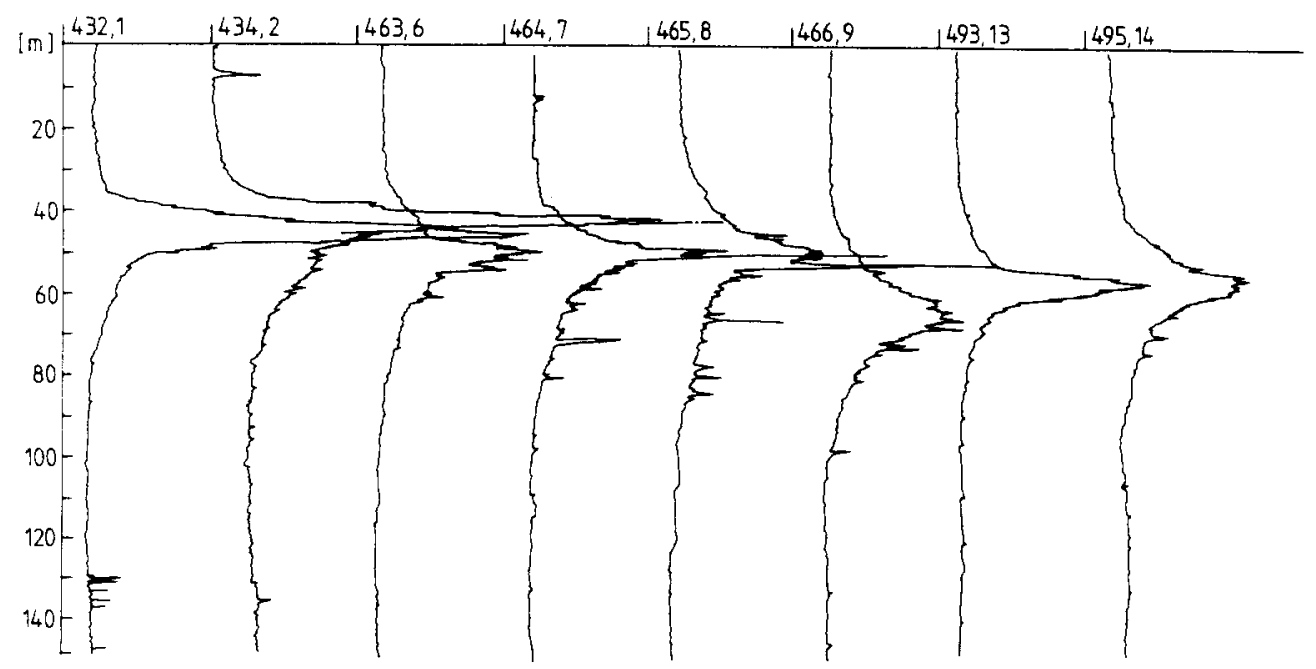

Fig. 14. In situ fluorescence on leg $3 b$, arbitrary units. Numbers indicate station and day of drift study. 
down to $45 \mathrm{~m}$. Below $120 \mathrm{~m}$ the anomaly of nitrate distribution due to bacterial denitrification typical for the Arabian Sea became obvious (see Mantoura et al., 1993) (Fig. 13).

Vertical profiles of in situ fluorescence (Fig. 14) and chlorophyll [Fig. 15(a)] show a prominent subsurface maximum, decreasing from $35-50 \mathrm{~m}$, at the beginning, to $45-70 \mathrm{~m}$. Chlorophyll concentrations were $0.11-0.18 \mu \mathrm{gl}^{-1}$ in the surface layer and as high as $1.40 \mu \mathrm{g}$ $1^{-1}$ (always $>0.8 \mu \mathrm{g} \mathrm{l}^{-1}$ ) in the subsurface maximum. The distinct subsurface maximum of

(a)

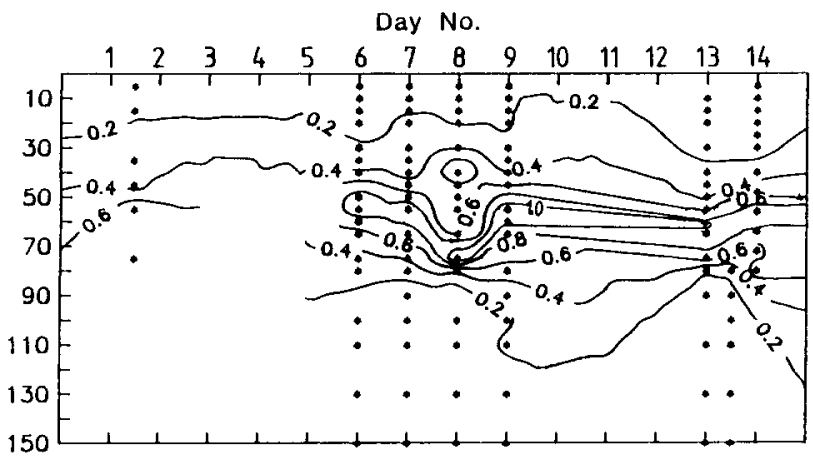

(b)

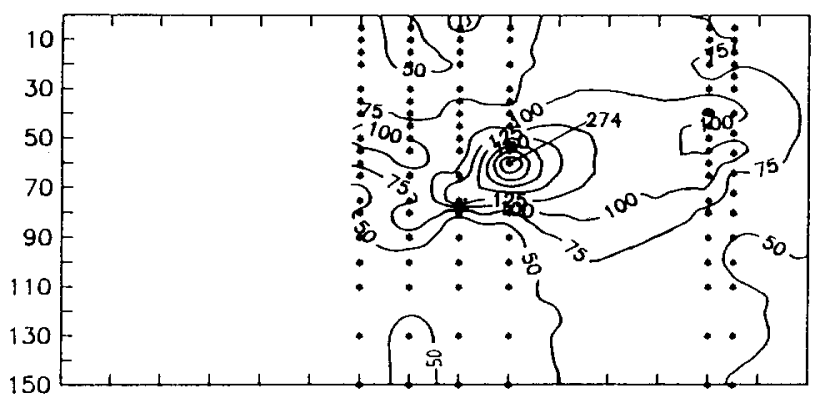

(c)

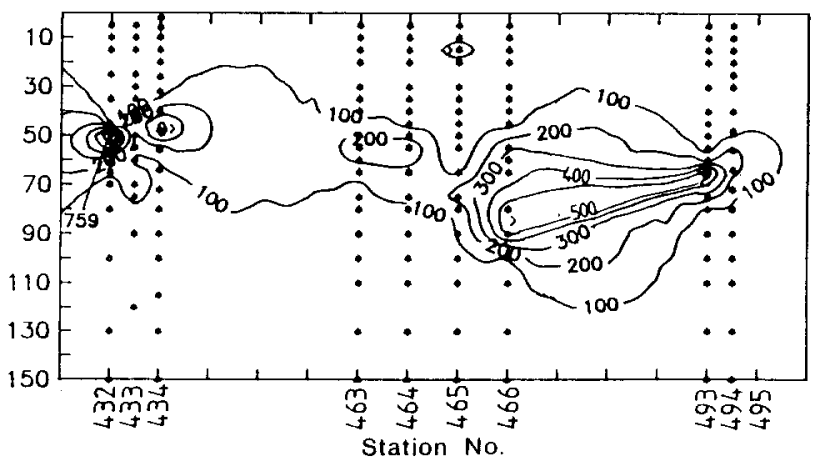

Fig. 15. Profiles of (a) chlorophyll $a$, (b) particulate organic carbon and (c) particulate silicate on leg $3 \mathrm{~b}$, all in $\left.\mu \mathrm{g}\right|^{-1}$. 


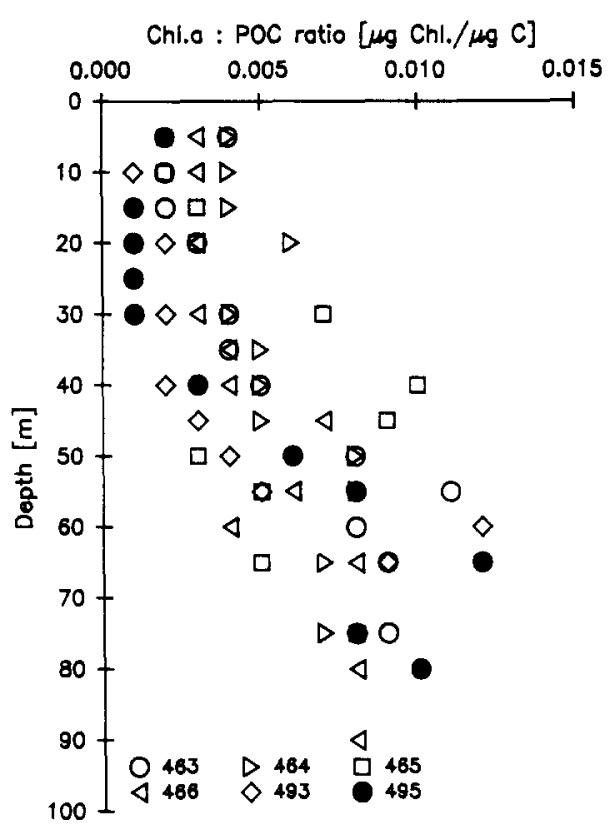

Fig. 16. Chl a/POC ratios on leg $3 b$.

particulate silicate [Fig. 15(c)] in the lower part of the chlorophyll maximum indicated the occurrence of diatoms.

POC, [up to $274 \mu \mathrm{g} \mathrm{I}^{-1}$; Fig. 15(b)] and PON (up to $47 \mu \mathrm{g} \mathrm{I}^{-1}$; not depicted) also showed distinct subsurface maxima coinciding with the chlorophyll maximum. The highest integrated chlorophyll was observed at Sta. 466 (day 9) and coincided with the highest values of $\mathrm{POC}, \mathrm{PON}$ and particulate silicate. Atomic $\mathrm{C} / \mathrm{N}$ ratios ranged between 5 and 7.3 , tending to slightly lower values in the surface layer. The low ratios again suggest a minor contribution from detritus; this was supported by microscopic observations. In the surface layer, Chl a/POC ratios (Fig. 17) were constant and much lower compared to leg 3a, indicating a higher significance of heterotrophic organisms. Chl a/POC ratios decreased from $30 \mathrm{~m}$ down to the bottom of the productive zone $(75 \mathrm{~m})$ and remained constant between 75 and $90 \mathrm{~m}$.

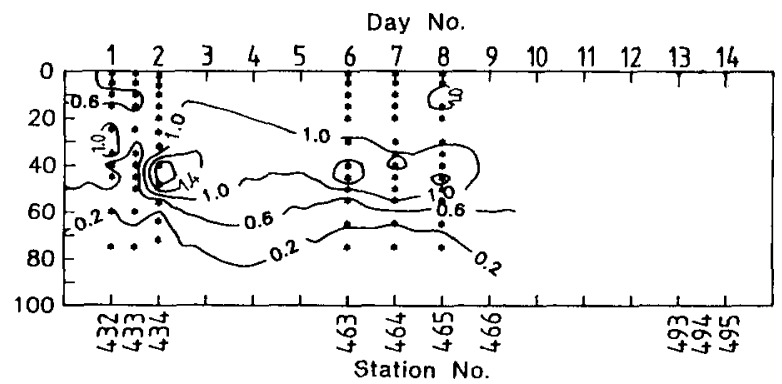

Fig. 17. Primary production $\left(\mu \mathrm{g} \mathrm{Cl}^{-1} \mathrm{~h}^{-1}\right)$ on leg $3 \mathrm{~b}$. 


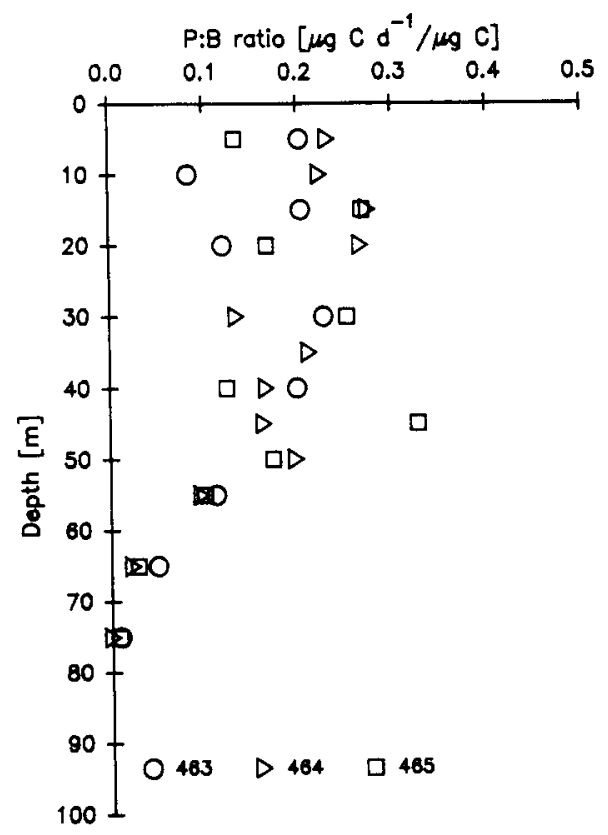

Fig. 18. $\mathrm{P}: \mathrm{B}$ ratios (daily primary production to particulate organic carbon) on leg $3 \mathrm{~b}$.

Except on day 1 (Stas 432 and 433), primary productivity showed a distinct subsurface maximum at $30-50 \mathrm{~m}$ depth [that is in the upper half of the subsurface chlorophyll maximum (Fig. 18)]. Surface production was about $0.6 \mu \mathrm{g} \mathrm{Cl}^{-1} \mathrm{~h}^{-1}$ and as high as $2.1 \mu \mathrm{g} \mathrm{C}$ $1^{-1} \mathrm{~h}^{-1}$ within the subsurface maximum (always $>1 \mu \mathrm{g} \mathrm{Cl}^{-1} \mathrm{~h}^{-1}$ ). Low rates of production could still be measured at $75 \mathrm{~m}$ depth. Integrated production amounted to about $0.7 \mathrm{~g} \mathrm{C}$ $\mathrm{m}^{-2}$ day $^{-1}$ (Table 1 ).

$\mathrm{P}: \mathrm{B}$ ratios (Fig. 18) were more or less constant down to $50 \mathrm{~m}$, but decreased sharply below this depth. This shape of profile is similar to that found during the last 3 days of leg $3 \mathrm{a}$, but the $\mathbf{P}: \mathbf{B}$ ratios were lower off the coast of Oman.

The production of all three size fractions was highest in the subsurface maximum, but the picoplankton maximum appeared in the upper half of the chlorophyll maximum, whereas that of micro- and nanoplankton occurred in the lower part. This vertical zonation within the subsurface maximum could, however, not be detected in chlorophyll measurements (JoCHEM, 1990). The picoplankton was the dominant size fraction, both in integrated primary production and chlorophyll.

\section{Leg $3 c$ : the shelf off Pakistan}

The drogue station on the shelf off Pakistan was investigated in two drift phases: days 1-2 (Stas 521-525); and days 6-12 (Stas 552-561). The drifter trajectory of this leg was very complicated, with the drogue frequently changing direction (Fig. 19). This indicates a highly dynamic area and makes it difficult to determine whether the data presented below can be seen as a true time series, particularly because hydrographic data were available only for three stations. The hydrographic data however, showed very similar profiles (Fig. 


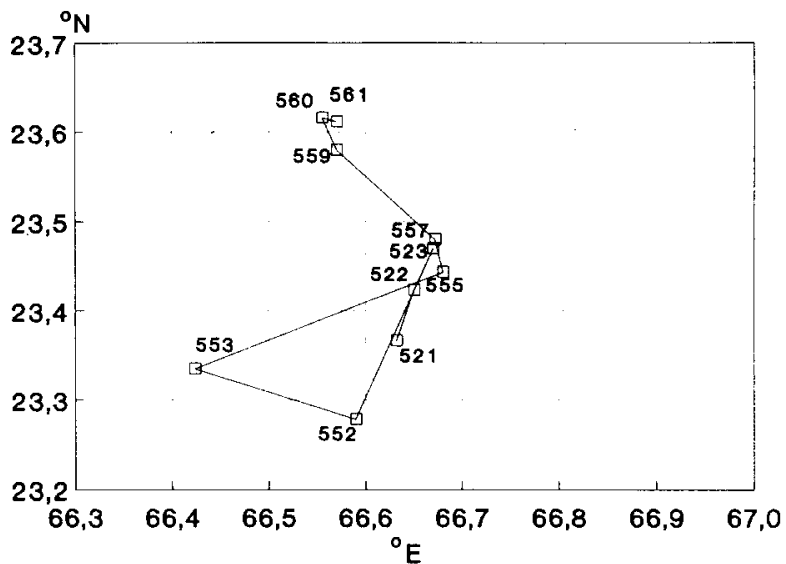

Fig. 19. Drifter trajectory of the drogue station on the shelf off Pakistan, leg $3 c$. Station numbers indicated.

20 ), with surface temperature being $28.7-29.8^{\circ} \mathrm{C}$ and surface salinity $36.9-37.1 \%$. The temperature and salinity were the highest of the three investigation areas. A salinity minimum was recorded between the main pycncocline (at about $20 \mathrm{~m}$ depth) and $60 \mathrm{~m}$ depth.

The nutrient regime on the shelf off Pakistan was very similar to that in the central Arabian Sea (Fig. 21) Surface layer concentrations were $0.3-0.45 \mu \mathrm{mol} 1^{-1}$ of phosphate and $0.6-1.3 \mu \mathrm{mol} \mathrm{I}^{-1}$ of silicate; the latter was variable but higher than on leg $3 \mathrm{~b}$. Both nitrate and nitrite were below the limit of detection down to $50 \mathrm{~m}$. The anomaly of nitrate distribution was obvious below $80 \mathrm{~m}$ depth. The nitrite maximum at $50-70 \mathrm{~m}$ was as high as $0.96 \mu \mathrm{mol} \mathrm{l}^{-1}$.

In situ fluorescence (Fig. 22) and chlorophyll [Fig. 23(a)] showed subsurface maxima at 30-50 $\mathrm{m}$ during drift phase I, and 40-60 m during drift phase II. Chlorophyll concentrations were about $0.15 \mu \mathrm{g} \mathrm{l}^{-1}$ in the surface layer and as high as $1.1 \mu \mathrm{g} \mathrm{l}^{-1}$ in the subsurface maximum. During drift phase II, a decrease of chlorophyll within the

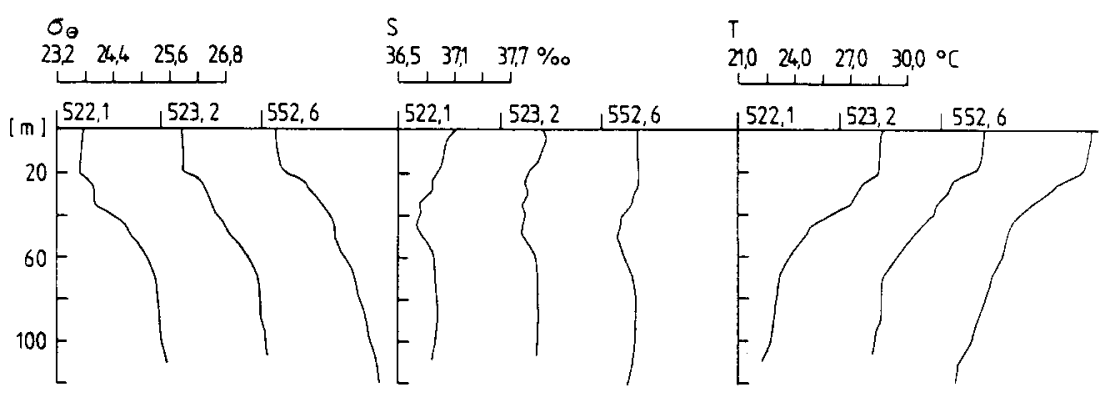

Fig. 20. Profiles of density $\sigma_{\theta}$, salinity $(\%)$, and temperature $\left({ }^{\circ} \mathrm{C}\right)$ on leg $3 \mathrm{c}$. Numbers indicate station and day of drift study. 


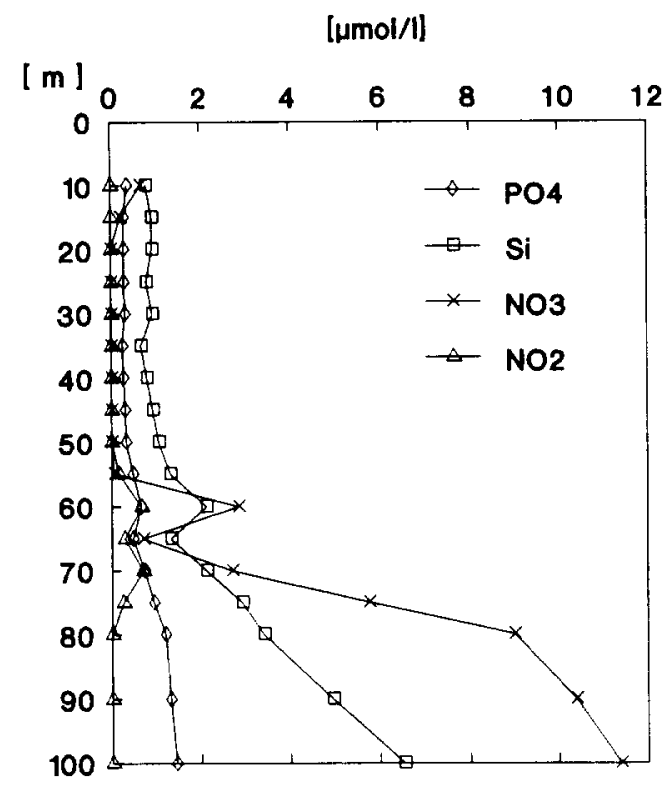

Fig. 21. Inorganic nutrients $\left(\mu \mathrm{mol} \mathrm{l}^{-1}\right)$ at Sta. 555 (day 8) on leg 3c.

subsurface maximum was noted. This decrease can also be seen in integrated values (Fig. 24), which decreased from $28 \mathrm{mg} \mathrm{m}^{-2}$ to $14 \mathrm{mg} \mathrm{m}^{-2}$ at Sta. 558 , but increased to 24.6 and $26.5 \mathrm{mg} \mathrm{m}^{-2}$ on the last 2 days.

Again, subsurface maxima of POC $\left[\leq 156 \mu \mathrm{g} \mathrm{l}^{-1}\right.$; Fig. 23(b)] and PON ( $\leq 34 \mu \mathrm{g} \mathrm{l}^{-1}$; not depicted) were recorded in the chlorophyll maximum. Like in the Arabian Sea, atomic $\mathrm{C} / \mathrm{N}$ ratios ranged between 5 and 7 , and between 7 and 8 in some samples from the depth range 60-100 $\mathrm{m}$. Particulate silicate had its maximum in the lower part of the chlorophyll maximum, indicating higher diatom abundance there [Fig. 23(c)]. Vertical profiles of Chl $a /$ POC (Fig. 25) strongly resembled those from the central Arabian Sea, i.e. constant ratios down to $30 \mathrm{~m}$, and an increase within the subsurface maximum. The ratios were, however, at the lower end of the range found in the central Arabian Sea.

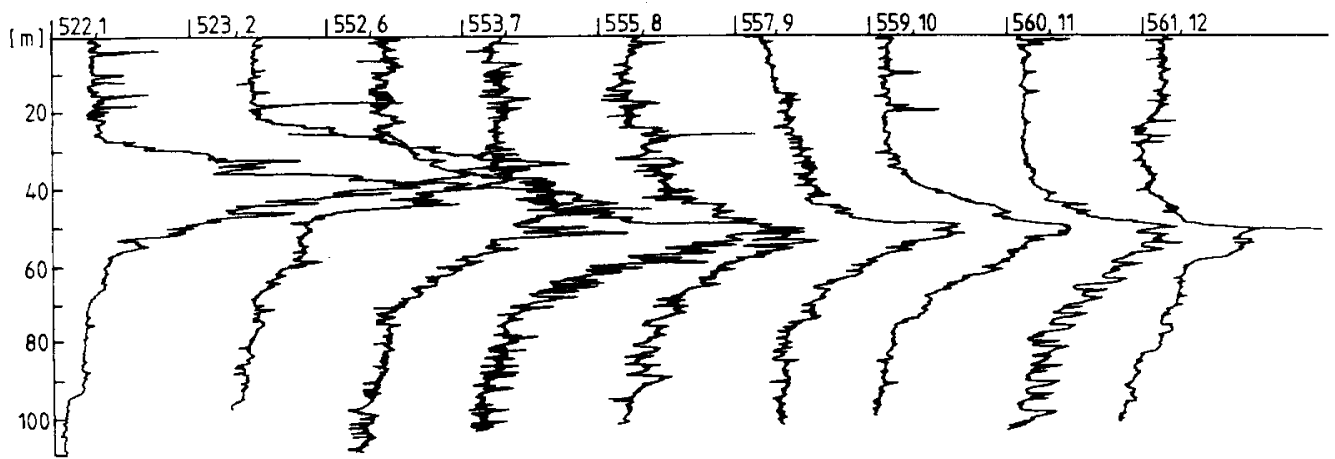

Fig. 22. In situ fluorescence on leg 3c, arbitrary units. Numbers indicate station and day of drogue station. 
(a) Day No.

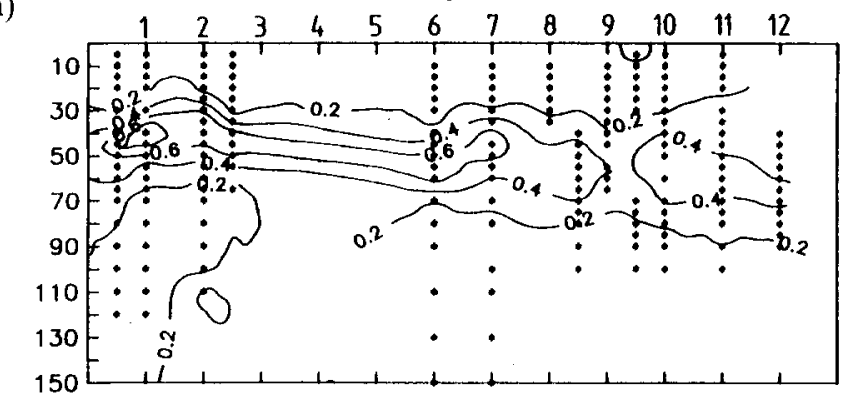

(b)

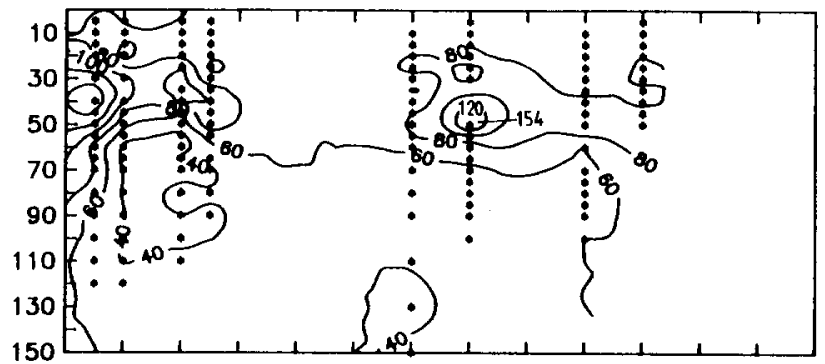

(c)

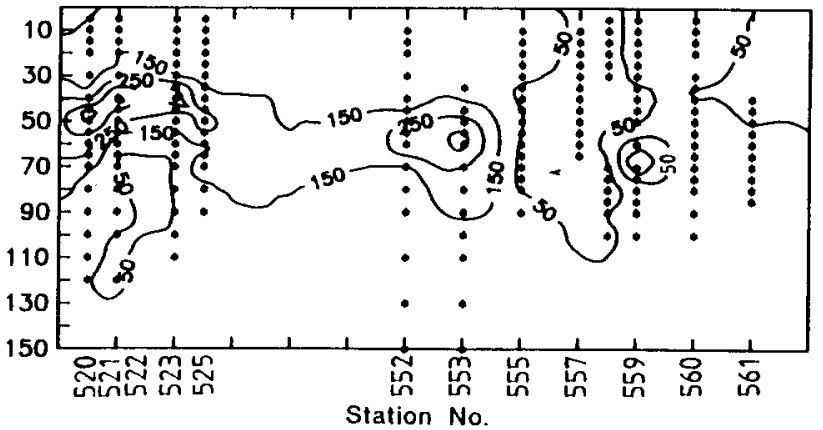

Fig. 23. Profiles of (a) chlorophyll $a$, (b) particulate organic carbon and (c) particulate silicate on leg $3 \mathrm{c}$, all in $\mu \mathrm{g} \mathrm{l}^{-1}$.

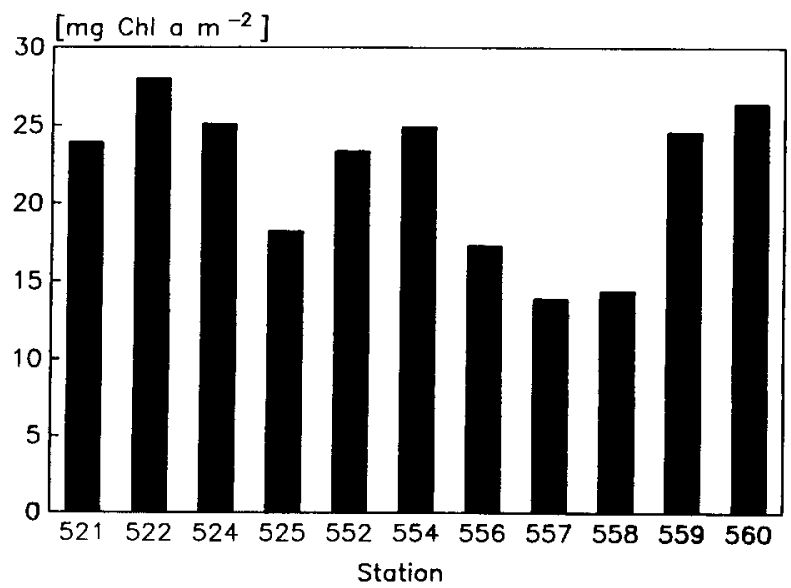

Fig. 24. Integrated chlorophyll $a(0-75 \mathrm{~m})$ on leg $3 \mathrm{c}\left(\mathrm{mg} \mathrm{m}^{-2}\right)$. 


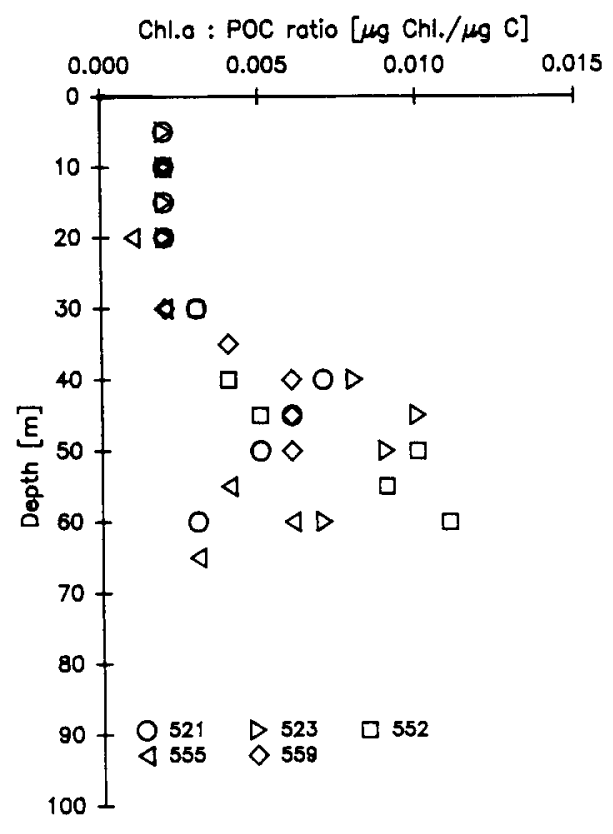

Fig. 25. Chl a/POC ratios on leg $3 \mathrm{c}$.

Primary production showed a subsurface maximum $\left(\leq 1.2 \mu \mathrm{g} \mathrm{Cl}^{-1} \mathrm{l}^{-1}\right)$ at $40-50 \mathrm{~m} \mathrm{depth}$ during drift phase I (Fig. 26) corresponding to fluoresence and chlorophyll profiles. During drift phase II, both a subsurface and a surface maximum occurred. The latter was most prominent $\left(\leq 2.6 \mu \mathrm{g} \mathrm{Cl}^{-1} \mathrm{~h}^{-1}\right.$ ) at Sta. 557 (day 9), and coincided with the occurrence of filamentous cyanobacteria which resulted in a more pronounced effect on productivity than on chlorophyll measurements. The integrated primary production (upper $75 \mathrm{~m}$ ) was $0.2-0.4 \mathrm{~g} \mathrm{C} \mathrm{m}^{-2} \mathrm{day}^{-1}$ but was as high as $0.6 \mathrm{~g} \mathrm{C} \mathrm{m}^{-2} \mathrm{day}^{-1}$ during the period of surface maxima (Fig. 27).

$\mathrm{P}: \mathrm{B}$ ratios (Fig. 28) were only half of those in the central Arabian Sea. Except for the last two days, the shape of the vertical profile was similar to that in the central Arabian Sea, displaying almost constant ratios from the surface down to $60 \mathrm{~m}$. On the last 2 days (Stas 555 and 559), however, the productivity surface maximum of filamentous cyanobacteria caused higher ratios in the surface waters, and thus a decrease with depth. The highest $\mathrm{P}: \mathrm{B}$

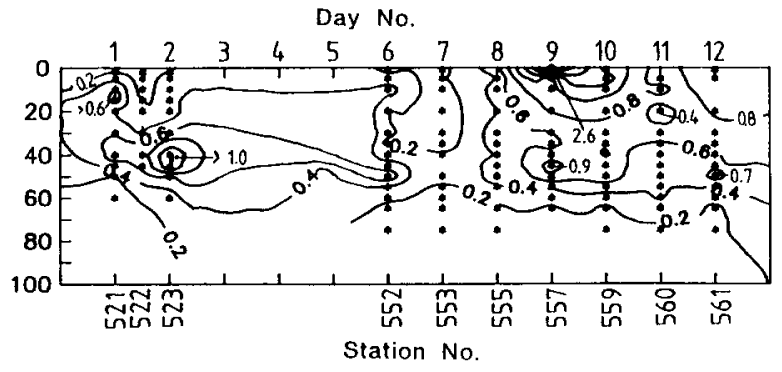

Fig. 26. Primary production $\left(\mu \mathrm{g} \mathrm{Cl} 1^{-1} \mathrm{~h}^{-1}\right)$ on leg $3 \mathrm{c}$. 

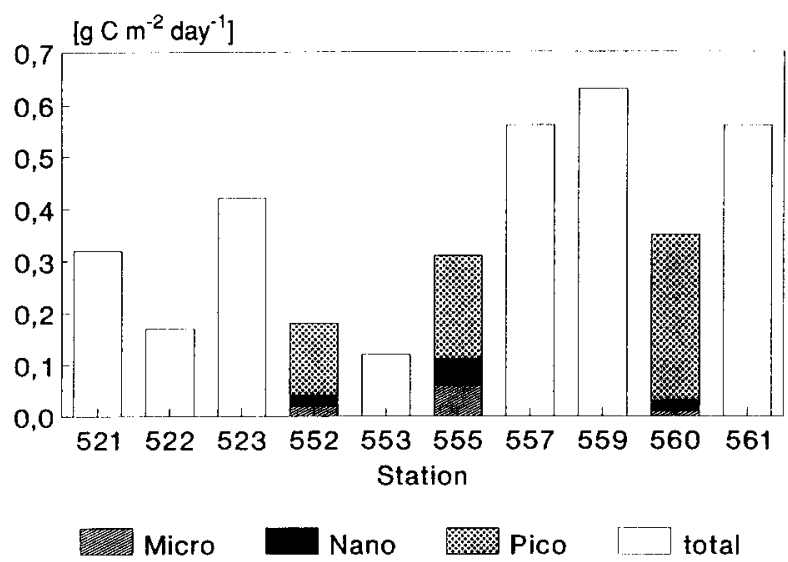

Fig. 27. Daily integrated, size-fractionated (where available) primary production $(0-75 \mathrm{~m}$; $\mathrm{g} \mathrm{C}$ $\mathrm{m}^{-2}$ day $^{-1}$ ) on leg $3 \mathrm{c}$.

ratios of the entire cruise were encountered during this phase of the investigation, and the shape of the profiles resembled that of the beginning of leg $3 a$ off the coast of Oman.

Only three size fractionation experiments for productivity, and one for chlorophyll, were available on leg $3 \mathrm{c}$ (Table 1). They showed picoplankton dominated both the primary production and autotrophic biomass (66-92\% of total). At Sta. 552 (day 6), however, $40 \%$ of the production was measured in the microplankton size class in the surface sample $(5 \mathrm{~m})$.

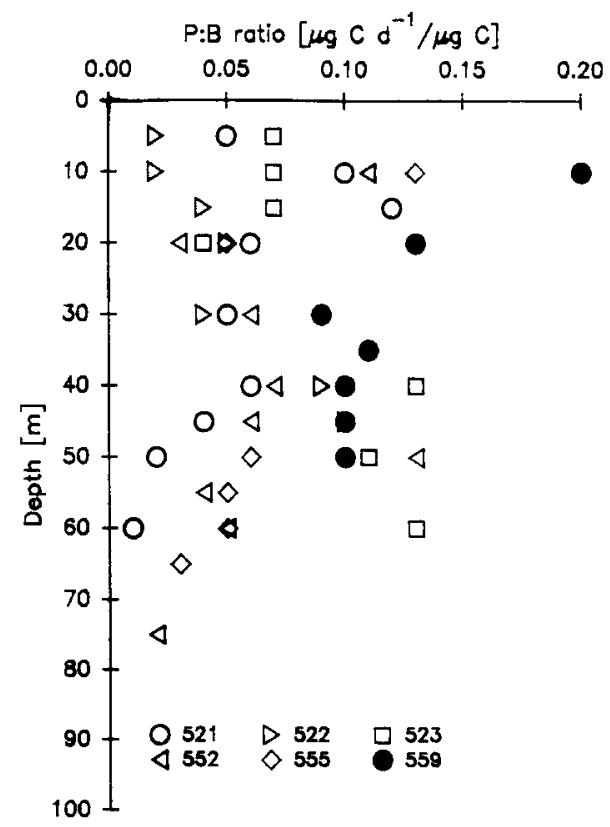

Fig. 28. $\mathrm{P}: \mathrm{B}$ ratios (daily primary production to particulate organic carbon) on leg $3 \mathrm{c}$. 


\section{DISCUSSION}

The investigation area off the coast of Oman showed the highest spatial and temporal variability among the three regions investigated. The relatively low temperatures $\left(25^{\circ} \mathrm{C}\right)$ may indicate that cold and nutrient-rich subsurface water may have been entrained into the euphotic zone immediately prior to the study. This is supported by low, but still measurable, nitrate concentrations in the surface layer at the beginning of the study. At the start of the drogue station, autotrophic biomass consisted of microplankton, namely diatoms like Rhizosolenia spp. (PAssow et al., 1993), and picoplankton in similar quantities. This size distribution changed with an increased significance of picoplankton along with decreasing nutrient concentrations, and the consolidation of the subsurface maximum. This change was accompanied by the highest sedimentation rates observed during this study, namely the sedimentation of diatoms, and auxospore-formation by Rhizosolenia spp. (PAssow et al., 1993), and a decrease in water column productivity. The decrease in autotrophic biomass and productivity was primarily governed by the decreased microphytoplankton.

The investigation area in the central Arabian Sea displayed high spatial (NELLEN et al., 1988; Pollehne et al., 1993a) and temporal homogeneity, and the epipelagic system can be considered to be in steady-state. As on the other legs, the depth of the nutricline showed no relation to physical structures and, therefore, was determined predominantly by biological activity.

Subsurface maxima of in situ fluorescence and chlorophyll, a well documented phenomenon in oligotrophic oceans, were related to the nutricline. Both accumulation of autotrophic biomass and an increase in cellular pigment content due to photoadaptation can cause such a maximum. There are several reports that subsurface maxima of chlorophyll do not necessarily reflect biomass maxima (Steele, 1964; BeErs et al., 1975; Cullen and Eppley, 1981; Kimor et al., 1987; Taguchi et al., 1988; Pillen, 1989). However, microscopic cell counts (Jochem, 1990), HPLC pigment analysis (PolleHNe et al., 1993a) and profiles of particulate silicate proved the subsurface chlorophyll maximum to be a biomass maximum as well. Since $\mathrm{Chl} a / \mathrm{POC}$ ratios increased below $30 \mathrm{~m}$, the subsurface maximum of POC also indicates the chlorophyll maximum being an algal biomass maximum. The subsurface maxima of primary production proved this subsurface population to be actively growing, and not a result of sedimenting biomass. Picoplankton was the dominant size fraction in both autotrophic biomass and primary production throughout the water column. While Synechococcus-type cyanobacteria were almost the only algae in surface layers, some larger phytoplankton occurred in the lower half of the subsurface maximum (Jochem, 1990; Passow et al., 1993; Pollehne et al., 1993a).

The vertical structure of physical, chemical and biological variables was very similar on the shelf off Pakistan and the central Arabian Sea. However, there was a prominent difference between autotrophic biomass and primary production, primarily due to lower values in the subsurface maximum layer and its decay over the study period. The epipelagic system of leg $3 \mathrm{c}$ can be interpreted as a water mass from offshore advected towards the coast of Pakistan/India and onto the shelf with the start of southwesterly monsoon winds in May. This advection, due to the nature of Ekman-transport, was most pronounced near the surface. Thus with decreasing depth on the shelf, the lower part of the water column was effectively "cut-off", leaving the euphotic zone without the underlying nutrient-rich waters. Consequently, the upward flux of nutrients decreased, 
decreased, and the euphotic zone became depleted of nutrients. This was clearly indicated by the depth below which nitrate could be detected; surface to $30 \mathrm{~m}$ at the beginning, but 55-60 $\mathrm{m}$ at the end of the drogue station.

The N:P ratios of inorganic nutrients never reached the Redfield uptake ratio of 15 (REDfield et al., 1963) and, therefore, phosphorus tended to accumulate in the euphotic zone of the Arabian Sea. This may favour the occurrence of filamentous diazotrophic bluegreens observed at the end of the study, leading to surface maxima in primary production. Primary productivity originating from the surface layer increased from $<50$ to $60-70 \%$ of water column productivity. Since picoplankton productivity also increased near the surface after filamentous cyanobacteria occurred (JocHEM, 1990), it is possible that fixed nitrogen was very rapidly channelled through the microbial loop, possibly via exudation by the cyanobacteria and subsequent remineralization by bacteria and microzooplankton. This was also reflected by an increase of $\mathrm{N}$-dependent bacterial processes (GIESENHAGEN, 1988).

\section{Different functional systems in the Arabian Sea}

Within a spatially homogeneous and temporally stable environment, the epipelagic system in the central Arabian Sea can be divided into two functionally different subsystems whose co-existence might be considered characteristic for (sub)tropical oceans (Pollehne et al., 1993a), the oligotrophic surface layer (SL) and the subsurface maximum layer (SML) at the nutricline.

In the SL, vertically constant $\mathrm{P}: \mathrm{B}$ ratios of phytoplankton suggest that primary production was not limited by light availability, but rather nutrient cycling dependent on heterotrophic activity. $50 \%$ of the water column productivity originated from the SL, having a much lower phytoplankton standing stock as compared to the SML. Turnover, therefore, was much faster in the SL [chlorophyll-specific production at the surface $>4 \mathrm{mg}$ $\mathrm{C}(\mathrm{mg} \mathrm{Chl})^{-1} \mathrm{~h}^{-1}$, as high as $9.7 \mathrm{mg} \mathrm{C}(\mathrm{mg} \mathrm{Chl})^{-1} \mathrm{~h}^{-1}$; JoCHEM, 1990]. Greskes and KraAY (1986) report a similar high biomass-normalized productivity [as high as $15 \mathrm{mg} \mathrm{C}$ ( $\mathrm{mg} \mathrm{Chl}$ $a)^{-1} \mathrm{~h}^{-1}$ ] in the surface layer of the tropical North Atlantic $\left(20^{\circ} \mathrm{N}, 20-40^{\circ} \mathrm{W}\right)$, but no increase of chlorophyll, indicating a high turnover of primary production rather than biomass accumulation. Losses of nutrient elements (N, P, Si) must be kept to a minimum; therefore sedimentation can be expected to be very low. In fact, sedimentation of chlorophyll measured in a Kiel sediment trap at $30 \mathrm{~m}$ depth was only minor, $9 \mu \mathrm{g} \mathrm{Chl} \mathrm{a} \mathrm{m}^{-2}$ day $^{-1}$ or $0.05-0.2 \%$ of the standing stock (NeLLen et al., 1988).

Within the SML, Chl $a / \mathrm{POC}$ ratios increased, probably reflecting both the increased contribution of phytoplankton to POC and the increase of cellular chlorophyll content due to photoadaptation. GIESKES and KRAAY (1986) report increased cellular chlorophyll for phytoplankton from the SML in the tropical North Atlantic in contrast to the SL, they also found an increase of chlorophyll within incubation bottles over $12 \mathrm{~h}$, indicating primary production leading to autotrophic biomass accumulation, thereby balancing sedimentation losses and stabilizing the subsurface maximum. At $80 \mathrm{~m}$ depth, sedimentation of 22 $\mathrm{mg} \mathrm{C} \mathrm{m}^{-2}$ day $^{-1}$ was measured (Pollehne et al., 1993b). Assuming that almost all of this sedimentation originated from the SML, it amounted to about $6 \%$ of daily production within this layer; it further accounted for $30-60 \%$ of microphytoplankton production, the size fraction most likely to sediment out of the water column. Some amounts of zeaxanthin, characteristic for picocyanobacteria, were also measured in the sediment traps 
so that some active pathways, most probably via grazing, contribute to the sedimentation. In contrast to the relatively closed surface system, the SML is open at its base. It is interesting that, despite high nutrient concentrations, small phototrophs, i.e. organisms less likely to sink, are the major primary producers at the bottom of the euphotic zone (Jochem, 1990). A detailed description of the two-layer system is given elsewhere in this volume (Pollehne et al., 1993a,b).

On leg 3a off the coast of Oman, successional stages towards the development of a twolayer system and the concomitant consolidation of the subsurface chlorophyll maximum could be observed. At the beginning of the study, surface $\mathrm{Chl} a / \mathrm{POC}$ ratios were much higher than on leg $3 \mathrm{~b}$, increasing with depth which most likely reflects photoadaptation. Profiles of $\mathrm{P}: \mathrm{B}$ ratios resembled those of light penetration into the ocean and indicate primary production probably being light- rather than nutrient-limited. After the hydrographic changes (days 7-9, stas 341-351), the subsurface maximum was more pronounced and profiles of $\mathrm{P}: \mathrm{B}$ ratios became more similar to those of leg $3 \mathrm{~b}$, no longer resembling light penetration curves and indicating a higher significance of nutrient limitation near the surface. Generally decreasing $\mathrm{Chl} a / \mathrm{POC}$ ratios point towards an increasing importance of heterotrophic biomass, accompanied by higher sedimentation. Size-fractionation as well as decreasing $\mathrm{C} / \mathrm{N}$ ratios throughout the euphotic zone reflected the change towards the predominance of smaller organisms. While $27-88 \%$ of community respiration was attributed to nanozooplankton $(<20 \mu \mathrm{m})$ at the start of leg $3 \mathrm{a}$, this was $66-97 \%$ at the end; the change in community size structure, thus, was also obvious in the heterotrophic compartments (NeLLEN et al., 1988).

The epipelagic system encountered on the shelf off Pakistan, on the other hand, can be seen as a decay stage of the two-layered system of the open oligotrophic ocean. While the vertical structure was very similar to that of leg $3 \mathrm{~b}$, autotrophic biomass and productivity were lower (except during the occurrence of filamentous cyanobacteria near the surface). $\mathrm{Chl} a / \mathrm{POC}$ ratios were in the lower range and $\mathrm{P}: \mathrm{B}$ ratios only half of those in the central Arabian Sea. The decrease of nutrients and heterotrophic processes gaining higher importance in community dynamics will, on a longer time scale, lead to a breakdown of this ecosystem. By the increasing monsoon winds, the water body will be advected further onto the shelf, and mixing with coastal waters will destroy the vertical structure and the equilibrium of processes in this ecosystem. Due to the drastic changes in wind direction and wind stress by the different monsoon regimes, this should be a recurrent seasonal phenomenon.

Acknowledgements-We thank Captain Kull and the crew of R.V. Meteor as well as all our colleagues involved in the cruise for their efficient help at sea. Measurements of inorganic nutrients and particulate carbon, nitrogen and silicate by Peter Fritsche and Rolf Werner are greatly appreciated. We greatly acknowledge the helpful comments on an carlier version of this manuscript by Marcel Veldhuis, Winfried Gieskes and one anonymous referee. This work was funded by Deutsche Forschungsgemeinschaft grants $\mathrm{Ne}-99 / 21$ and Zc-119/10. We dedicate this contribution to the memory of our friends and colleagues Annette Barthelt, Marco Buchalla, HansWilhelm Halbeisen and Daniel Reinschmidt, whose lives were taken by the insanity of terrorism in Djibouti on the day prior to the cruise. 


\section{REFERENCES}

ANGEL M. V. (1984) Marine science of the northwest Indian Ocean and adjacent waters. Deep-Sea Research, 31, 1-1035.

Beers J. R., M. H. Reid and G. L. Stewart (1975) Microplankton of the North Pacific central gyre. Population structure and abundance, June 1973. International Revue der gesamten Hydrobiologie and Hydrographie 60, 707-737.

Bratbak G. (1985) Bacterial biovolume and biomass estimations. Applied Environmental Microbiology. 49. 1488-1493.

Cullen J. J. and R. W. EPpley (1981) Chlorophyll maximum layers of the southern California Bight and possible mechanisms of their formation and maintenance. Oceanologica Acta 4, 23-32.

GaLlagher J. F. (1966) The variability of water masses in the Indian Ocean. National Oceanographic Data Center Publication G-11. Washington, D.C.

Giesenhagen H. C. (1988) Zur Verteilung heterotropher Aktivität und bakterieller Sekundärproduktion im Küstenbereich des Arabischen Meeres zum Beginn des Südwest-Mosuns. Diploma thesis, Kiel University. $99 \mathrm{pp}$.

Gieskes W. W. C. and G. W. KraAy (1986) Floristic and physiological differences between the shallow and the deep nanophytoplankton community in the euphotic zone of the open tropical Atlantic revealed by HPLC analysis of pigments. Marine Biology, 91, 567-576.

Grasshoff K., M. Ehrhardt and K. Kremling (1983) Methods of seawater analysis. 2nd edition. Verlag Chemie, Weinheim.

JEFFrEy S. W. and G. F. HumPhrey (1975) New spectrophotometric equations for determining chlorophyl!' a, b, $c_{1}, c_{2}$ in higher plants and phytoplankton. Biochemie und Physiologie der Pflanzen, 167, 191-194.

Jocheм F. J. (1990) Zur Struktur und Dynamik autotropher Ultraplankton-Gemeinschaften in mariner Warmwasser-Ökosystemen. Berichte Institut für Meereskunde, Kiel 195, $220 \mathrm{pp}$.

Kimor B., T. Berman and A. Schneller (1987) Phytoplankton assemblages in the deep chlorophyll layers oif Mediterranean coast of Israel. Journal of Plankton Research, 9, 433-443.

Legendre L., S. Demers, C. M. Yentsch and C. S. Yentsch, (1983) The ${ }^{14}$ C method: patterns of dark $\mathrm{CO}_{2}$ fixation and DCMU correction to replace the dark bottle. Limnology and Oceanography, 28, 996-1003.

Mantoura R. F. C., C. S. Law, N. J. P. Owens, P. H. Burkill, E. M. S. Woodward, R. J. M. Holland and C. A. Llewellyn (1993) Nutrient biogeochemical cycling in the northwest Indian Ocean. Deep-Sea Research $I I, 40,651-671$.

Nellen W., D. Schnack and B. Zeitzschel (1988) Expeditionsbericht über die Meteor-Reise Nr. 5 Abschnitt 3. Berichte Zentrum für Meers- und Klimaforschung Universität Hamburg 0, 165 pp.

PAASCHE E. (1980) Silicon content of five marine diatom species measured with a rapid filter method. Limnology and Oceanography, 25, 474-480.

Passow U., R. Peinert and B. Zeitzschel (1993) Distribution of suspended matter as related to pelagic sedimentation during the intermonsoon period off Oman (West Arabian Sea). Deep-Sea Research II, 40, $833-849$.

Pillen T. (1989) Zur Phytoplanktonverteilung im Roten Meer und Golf von Aden während der MeteorExpedition (MINDIK 5/2) im Frühjahr 1987. Diploma thesis, Kiel University. 149 pp.

Poliehne F., A. Klein and B. Zeitzschel (1993a) Low light adaptation and export production in the deep chlorophyll maximum layer in the northern Indian Ocean. Deep-Sea Research II, 40, 737-752.

Pollehne F., B. Zeitzschel and R. Peinert (1993b) Short term sedimentation pattern in the northern Indian Ocean. Deep-Sea Research II, 40, 821-831.

QAsim S. Z. (1982) Oceanography of the northern Arabian Sca. Deep-Sea Research, 29, 1041-1068.

Redfield A. C., B. H. Ketchum and F. A. Richards (1963) The influence of organisms on the composition of sea water. In: The Sea, Vol. 2, M. N. Hill, editor, Interscience Publications, Wiley \& Sons, New York.

Ryther J. H., J. R. Hell, A. K. Pease, A. Bakun and M. M. Jones (1966) Primary production in relation to the chemistry and hydrography of the western Indian Ocean. Limnology and Oceanography, 11, 371-380.

SAStry J. S. and R. S. DeSouzA (1972) Upwelling and upward mixing in the Arabian Sea. Indian Journal of Marine Science, 1, 17-27.

Steele J. H. (1964) A study of production in the Gulf of Mexico. Journal of Marine Research, 3, $211-222$.

SteEmann Nielsen E. (1952) The use of radioactive carbon $\left({ }^{14} \mathrm{C}\right)$ for measuring organic production in the sea. Journal du Conseil permanent international pour l'exploration de la mer, 18, 117-140.

STrickl.And J. H. and T. R. PARsons, (1972) A practical handbook of seawater analysis. 2nd edition. Bulletin of the Fisheries Research Board of Canada 167, 310 pp. 
Taguchi S., G. R. DiTullio and E. A. LAws (1988) Physiological characteristics and production of surface layer and chlorophyll maximum phytoplankton populations in the Caribbean Sean and western Atlantic Ocean. Deep-Sea Research, 35, 1363-1377.

Zeitzschel B. (1973) The biology of the Indian Ocean. Springer, Berlin. $549 \mathrm{pp}$. 